\title{
A Preliminary Study On The Learning Perspective At Malaysia's Government Technical Department
}

\author{
Noor'Ain Zainal Abidin ${ }^{1, a^{*}}$, Mohamad Syazli Fathi ${ }^{2, b}$, Mohd Yusof Md Daud \\ and Harmi Izzuan Baharum ${ }^{4, d}$
}
1,2,3 UTM Razak School of Engineering and Advanced Technology, Universiti Teknologi Malaysia, Kuala Lumpur, Malaysia

${ }^{4}$ UTM Language Academy, Universiti Teknologi Malaysia, Kuala Lumpur, Malaysia

akkhh70@yahoo.com, bsyazli@utm.my, cyusof@ic.utm.my, dharmi@ic.utm.my

Keywords: learning, motivation, learning organization, learning culture

\begin{abstract}
A project manager is responsible for the successful project delivery. The project manager needs to effectively manage his team and all resources, in order to ensure the project is completed within the constraint of cost, schedule and quality, and also meeting the client's satisfaction. Looking at project complexity nowadays, the project manager and project team member are required to acquire new knowledge and develop new skill from time to time. Time is not a privilege as ones handle more than one project at one time. Hence, the objectives of the study are to investigate their perspective towards learning and their perception on organizational support on learning. The study was conducted at a Malaysia's Government technical department located in Klang Valley. 340 questionnaires were distributed and the rate of responses was about 53\%. It was a quantitative approach and the analysis is mainly descriptive. The study demonstrated that all respondents realize the importance of learning and they are motivated to learn. They also perceived that there is organizational support towards learning, thus create a learning culture in the organization. Future studies should be undertaken to address the issue of what is the appropriate learning approach to enhance project management learning.
\end{abstract}

\section{Introduction}

Knowledge is a powerful tool for surviving in today's world of globalization and rapid information exchange. Knowledge can be defined as "facts, information and skills acquired through experience and education" [1]. Knowledge gained by an individual is kept in one's mind. Since knowledge needs to be acquired by the person before it could be used by an organization, a knowledgeable person is highly sought by an organization, which in fact willing to pay high income to obtain the person. The expansion of knowledge requires learning from an individual or organization. Learning at working levels is related to competency to a designated job and enhancing existing skill to cope out with the challenges in the job scope and business environment.

An appointed project manager is required to lead his project team towards achieving the project objectives [2]. Throughout the project life cycle, the project manager is dealing and interacting with his project team, the functional management, senior management and client management, and handled crises if any conflict arises [3]. Therefore, a proficient project manager must have the right competency ([4], [5]) to ensure successful project delivery. A project manager is competent when he or she has the knowledge, personal attitudes, skills and experience required to successfully carry out the job function [6]. According to International Project Management Association (IPMA), three broad competencies required in project management are contextual, technical and behavior [6].

Project success is defined in many ways. Among other, a project that meets the specified time, cost, quality and client satisfaction is said to be successful ([7], [8], [9]). Many researchers ([10], [11], [12]) had studied on the critical succes factors for projects and revealed that among the factors are project goals, top management support, project schedule, project manager competency, project team member competency, knowledge on project management, financial capability, project objectives, communication and others. Consequently from the studies, there is a significant 
contribution of project manager or project team member competency to project success. For this reason, it is vital for a project manager or his team members to realize that they are required to enhance competency from time to time to effectively handle any new issues or changes required in a project. According to ([13], [14]), competency is developed through the process of learning.

Structured training provided by the organization is a form of formal learning ([15], [16]. The number of training carried out per year depends on the budget received by the department. Informal learning is also gained at workplace through self-directed learning, social learning, networking, coaching and mentoring [17]. Normally, a project manager and his team member handle more than one project at one time. On that account, they have limited time to attend a classroom training. In addition to that, the opportunity to learn from structured training is also limited as the number of professionals in the department is vast. Therefore, informal learning is required to support individual learning. The questions to be answered in this study is how the individual (project manager or project team member) forsee learning and what are their perception on the organizational support towards learning. Learning increases project competency, consequently contribute to project success. An organization that supports learning will improve its performance.

The following sections of this paper focus on the literature review related to motivation and learning culture. Next, the research design is going to be described and the findings will be presented and results from the distributed questionnaires. Lastly, the discussion of the findings and the conclusion of the study.

\section{Literature Review}

\section{Motivation}

Motivation can be defined as forces that encourage an individual to be constantly keen and devoted to a job, role or subject and to apply tenacious effort in achieving an objective [18]. The forces can be either from internal (intrinsic), i.e. within oneself, or external (extrinsic) from others or surroundings, or both. Based on Maslow's Hierachy of Needs, there are five basic needs required by an individual, i.e. physiological, safety, belongingness, esteem and self-actualization [19]. Learning is one aspect of life to fulfill the needs. Thus, the reasons for learning among individuals differ at every stage of individual's life. Motivation to learn is defined as an individual inclination to discover learning activities significance and advantangeous to the individual [20]. Project manager and project team member are adult learners. Among the traits of adult learners are have first hand experience, set habits and strong tastes, great deal of pride (their ways of showing it varies), establsihed a rational framework (values, attitudes, etc.) and want a choice in what they learn [21]. Therefore, adult learners's motivation to learn is based on their individual experiences, aptitude and attitude [21]. Human resource is the major asset of an organization. In order to remain competitive, an organization needs to ensure its human resource fully developed [18]. For that reason, the human resource has to have motivation learn in order to be knowledgeable and skilfull project manager and project team member.

\section{Learning culture}

Learning is the process of knowledge creation as a result of experience metamorphosis. Learning occurs at all life phases, i.e. from child to teenager, to midlife and old ages [13]. Culture could be defined as instill learned behavior patterns that were acted out oblivious or automatically [22]. An organization which encourages learning to its employees in all aspects and change accordingly to business environment is known as learning organization [23]. A learning organization would focus on the creativity and innovation as its strategic aim, in order to be able to maintain competitiveness [24]. The learning environment will create a culture which is hunger for knowledge continuously. Training is a formal learning provided by an organization. It is crucial to employees as it support them for the required skills and capabilities. A large number of organizations contribute 3 to $5 \%$ of their income into employees training [23]. A study by Miha et al. [25] stated that organization with learning culture has an effect on organizational performance. The investment in learning organizations could better improve the relationship inside and outside the organization, which bring 
to increase in profit. Another study by Muhammad Ehsan \& Rizwan [26] proofed the correlation motivation learn and organizational learning culture; and between job satisfaction and organizational learning culture. Given these points, it could be concluded that the learning culture plays a vital function in learning and organizational performance.

\section{Research Design}

This is a preliminary study to explore the issues related to learning perspective. From this study, the researcher hopes to identify salient points to proceed further. The respondents were employees of Malaysia's Government Technical Department. Using a quantitative approach, a questionnaire was administered to the respondents during training session, at the workshop and seminar. 340 questionnaires distributed and only 179 feedbacks received. Thus, the response rate is 53\%. After the data had been keyed in, it was found that there were respondents who did not fully filled in the questionnaire. This reduces the responses of $53 \%$ earlier. The questionnaire has four (4) main sections, i.e. respondent background, competency and learning, organizational role and human resource development. The questionnaire was developed using Likert Scale 1 to 5. Likert Scale is used as it is a recognized instrumentation for measuring peoples' attitudes. According to Rensis Likert, a person behaves similarly towards any issue, along negative-to-positive dimension. Advantages of Likert scale are its simpliciry and versatility [27]. The measurement scale used for this is study is 1 refers to 'strongly disagree' and 5 as 'strongly agree'.

\section{Findings}

Using statistical software, the findings are as below:

(a) Respondent's Background

The information gained from the data on respondent's background indicate that:

- $57 \%$ are female employees;

- $28 \%$ of them are generation Y (20 - 31 years old), $51 \%$ generation X (32- 49 years old) and $21 \%$ are categorized as baby boomers (50 years old and above) [28]

- Based on job position, basically there are 3 levels: top management (3\%), middle management (15\%) and the low level management (82\%).

- Top 3 disciplines during the survey were: civil (72\%), architectural (10\%) and quantity surveyor $(6 \%)$. Other disciplines: electrical (5\%), mechanical $(5 \%)$, building surveyor $(1 \%)$ and others $(1 \%)$.

\section{(b) Descriptive Analysis}

There are ten (10) questions related to individual learning with a measurement scale of 1 to 5 . Reliability analysis was carried out for these questions to show that whatever scale/instrument used, it is consistently measures whatever it is measuring. The calculated Cronbach's alpha was 0.963. The value of alpha is more than 0.70 , it means that the scale has internal consistency and reliability [29]. The results for mode factor showed 60\% - 4 (agree) and 40\% - 5 (strongly agree). While, the median scores gave values of $70 \%-4$ and $30 \%-5$. Variance is selected to establish the dispersion of score in distribution[30]. The lowest score is 1.093 for the question on "I'm motivated to enhance my existing knowledge and skill". At the same time, the highest score is 1.950 for the question on "I have ICT skills to obtain on the course / training related to my field".

Questions on organizational role are to investigate on organizational support towards learning based on the respondents' perceptions. There were 15 questions to be answered with a Likert Scale (1 to 5). Reliability check indicated that the value of Cronbach's alpha was 0.970 . This indicated the scale has internal consistency. The results for mode gave the value of 4 (agreed) $-60 \%, 3$ (neutral) $-33 \%$ and 2 (disagree) $-7 \%$. Next, the median scores were $4-73 \%, 3-20 \%$ and $2-7 \%$. The lowest variance score was 1.851 for the question on "The department support individual training and development". While, question on "Superior / performance assessment officer will call me back to the office during my training" has the highest score of 3.535 . 


\section{Discussions}

The analysis of individual learning based on the results from the mode and median factors showed that all the respondents are agreed on the importance of learning. The small variance demonstrates that the responses given by individuals are close to one another. In short, they are motivated to enhance their existing knowledge and skills. On the other hand, the highest variance score indicates large dispersion of opinion on having ICT skills. The knowledge gained from learning is valuable in term of enhancing their existing skills and promote creativity and innovation in their works. It was mentioned by [26] that a condition for learning is the motivation to learn. The analysis presented confirmed with this statement. The impact of learning is then translated into actions. One of project success factor is the competency of the people. Therefore, the people need to have the right fusion of skills and motivation [31]. Learning is essential in providing the people with the right skills and capabilities. The findings on organizational role illustrated that only $60 \%$ respondents perceived the organizational support towards learning. Nevertheless, based on the smallest variance value, they do believe the department does support individual learning and development. Hence, there exists a learning culture within the department. This study was an eye opener to the researcher on the issues related to learning in the Malaysia's Government technical department. They required learning to remain competitive and at the same time they have limited time for learning. There is also a need to increase the learning culture on the management side.

\section{Conclusion and future research}

This is a preliminary study to investigate the learning perspective at Malaysia's Government technical department. The findings demonstrate that the respondents are motivated to learn and there exist a learning culture within the department. Since the individual is motivated to learn on his own, future research that can be inspired is the appropriate learning approach to support existing learning provided by the department.

\section{Acknowledgement}

This work was financially supported by Universiti Teknologi Malaysia and the Ministry of Education (FRGS grant no: 4F388).

\section{References}

[1.] Oxford Dictionaries. Definition of knowledge. Available from: http://www.oxforddictionaries.com/definition/english/knowledge.

[2.] PMI, P.M.I., A Guide To The Project Management Body Of Knowledge (PMBOK Guide). 2008, Project Management Institute, Inc.: USA. p. 506.

[3.] Kerzner, H., Project Management A Systems Approach To Planning, Scheduling And Controlling. 2009, USA: John Wilet \& Sons, Inc. 1121.

[4.] Carbone, T.A., Developing project and program managers: A blended learning approach, in 2006 IEEE/SEMI Advanced Semiconductor Manufacturing Conference and Workshop. 2006, IEEE: New York. p. 353-357.

[5.] Otsuki, M., M. Samejima, and Ieee, An Intelligent Tutoring System for Case-Based eLearning on Project Management. 2013 Ieee International Conference on Systems, Man, and Cybernetics (Smc 2013), 2013: p. 3471-3476.

[6.] IPMA, I.P.M.A., ICB - IPMA Competence Baseline, Version 3.0. 2006, International Project Management Association: Netherlands. p. 1 - 213.

[7.] Belassi, W. and O.I. Tukel, A new framework for determining critical success/failure factors in projects. International Journal of Project Management, 1996. 14(3): p. 141 - 151.

[8.] Nguyen, L.D., S.O. Ogunlana, and D.T.X. Lan, A study on project success factors in large construction projects in Vietnam. Engineering Construction and Architectural Management, 2004. 11(6): p. 404 - 413.

[9.] Davis, K., Different stakeholder groups and their perceptions of project success. International Journal of Project Management, 2014. 32: p. 189 - 209. 
[10.] Cleland, D.I. and W.R. King Systems analysis and project management. 1975.

[11.] Lim, C.S. and M.Z. Mohamed, Criteria of project success: an exploratory re-examination. International Journal of Project Management, 1999. 17(4): p. 243 - 248.

[12.] Micheal, J., T. Deepak, and I.S.Y. Tong, Ranking the Factors that Influence the Construction Project Management Success: Malaysian Perspective. Civil and Environmental Research, 2014. 6(1): p. 80-88.

[13.] Kolb, D.A., Experiential learning: Experience as the source of learning and development. Vol. 1. 1984: Prentice-Hall Englewood Cliffs, NJ.

[14.] Kong, H. and Q. Yan, The relationship between learning satisfaction and career competencies. International Journal of Hospitality Management, 2014. 41(0): p. 133-139.

[15.] Jacobs, R.L., Training and Learning in the Workplace, in International Encyclopedia of Education (Third Edition), P.P.B. McGaw, Editor. 2010, Elsevier: Oxford. p. 328-336.

[16.] Svensson, L., P.-E. Ellström, and C. Åberg, Integrating formal and informal learning at work. Journal of Workplace Learning, 2004. 16(8): p. 479-491.

[17.] Ellinger, A.D., Contextual factors influencing informal learning in a workplace setting: The case of "reinventing itself company". Human resource development quarterly, 2005. 16(3): p. 389-415.

[18.] Gollu, E. and A. Kayi, Impact of Personal Development Trainings on Employee Motivation: A Case Study from Turkish Pharmaceuticals Sector, in EBES 2012 Antalya Conference. 2012: Antalya Turkey. p. 173 - 183.

[19.] Lauby, S.J., Employee Motivation, in Motivating Employees, B. Kaye, Editor. 2005, ASTD Press. p. 1 - 4.

[20.] Wlodkowski, R. and T. Westover, Accelerated courses as a learning format for adults. Canadian Journal for the Study of Adult Education, 1999. 13(1): p. 1-20.

[21.] Thoms, K.J., They're Not Just Big Kids: Motivating Adult Learners. 2001.

[22.] Ahmad, B.E. and F.A. Majid, Self-directed Learning and Culture: A Study on Malay Adult Learners. Procedia - Social and Behavioral Sciences, 2010. 7(0): p. 254-263.

[23.] Vemic, J., Employee training and development and the learning organization. Economics and Organization, 2007. Vol 4(2): p. 209 - 216.

[24.] Ahmed, C.L.W.P.K., Organizational learning: a critical review. The Learning Organization, 2003. 10(1): p. 8 - 17.

[25.] Skerlavaj, M., et al., Organizational learning culture: the missing link between business process change and organizational performance. International Journal of Production Economics, 2007. 106: p. 346 - 367.

[26.] Malik, M.E. and R.Q. Danish, Impact of motivation to learn and job attitudes on organizational learning culture in a public service organization of Pakistan. Research Journal of South Asian Studies, 2010. 25(2): p. 217 - 235.

[27.] Johns, R. Likert Items and Scales. 2010. 1-9.

[28.] Glass, A., Understanding generational differences for competitive success. Industrial and Commercial Training, 2007. 39(2): p. 98-103.

[29.] Santos, J.R.A., Cronbach's alpha: A tool for assessing the reliability of scales. Journal of extension, 1999. 37(2): p. 1-5.

[30.] Piaw, C.Y., Mastering Research Statistics. 2013, Malaysia: McGraw-Hill Education (Malaysia) Sdn. Bhd,

[31.] Ayas, K., Professional project management: a shift towards learning and a knowledge creating structure. International Journal of Project Management, 1996. 4(3): p. 131 - 136. 